Article

\title{
Applying UTAUT in Predicting ESL Lecturers Intention to Use Flipped Learning
}

\author{
Siti Fatimah Abd Rahman ${ }^{1}\left(\mathbb{D}\right.$, Melor Md Yunus $^{2}$ (D) and Harwati Hashim ${ }^{2, *(D)}$ \\ 1 Kulliyyah of Education, International Islamic University Malaysia (IIUM), Selangor 53100, Malaysia; \\ sfarahman@iium.edu.my \\ 2 Faculty of Education, Universiti Kebangsaan Malaysia (UKM), Selangor 43600, Malaysia; melor@ukm.edu.my \\ * Correspondence: harwati@ukm.edu.my
}

check for

updates

Citation: Abd Rahman, S.F.; Md Yunus, M.; Hashim, H. Applying UTAUT in Predicting ESL Lecturers Intention to Use Flipped Learning. Sustainability 2021, 13, 8571. https: //doi.org/10.3390/su13158571

Academic Editors: Jordi

Colomer Feliu, Hong-Ren Chen, Hao-Chiang Koong Lin and Wen-Shan Lin

Received: 3 June 2021

Accepted: 28 July 2021

Published: 31 July 2021

Publisher's Note: MDPI stays neutral with regard to jurisdictional claims in published maps and institutional affiliations.

Copyright: (c) 2021 by the authors. Licensee MDPI, Basel, Switzerland. This article is an open access article distributed under the terms and conditions of the Creative Commons Attribution (CC BY) license (https:// creativecommons.org/licenses/by/ $4.0 /)$.

\begin{abstract}
Flipped learning empowers learners to take an engaging role in learning while educators assist the learning process. The employment of flipped learning has been confirmed to enhance the teaching and learning of English as a second language in previous studies. This study aimed to explore the application of the unified theory of technology acceptance and use of technology towards ESL lecturers' intention to use flipped learning. This study used a quantitative research framework where a set of online questionnaires was used in collecting the data. A total of 206 English as a second language lecturers from four different universities participated in this study. The data were analyzed using structural equation modeling. The result of this study indicates that only social influence is significant in predicting English as a second language lecturers' intention to use the flipped learning approach. Furthermore, this study enriches the literature on 21st century education and the integration of technology in teaching and learning. In addition, this study could help educators and stakeholders in adapting or enhancing the flipped learning approach by distinguishing the distinct predictors of technology acceptance.
\end{abstract}

Keywords: flipped learning; UTAUT; technology acceptance; technology-enhanced education; ESL; higher education; life-long learning; 21st century of education; technological pedagogical content knowledge; educational technology

\section{Introduction}

The world is changing because of the fast growth of technologies and communication systems. The world is becoming smaller as communications are readily accessible in every part of the world using the internet [1]. Technology-integrated learning is very common in 21st century education [2] as it provides rich resources to technology-based education [3]. The powerful internet has changed the young generation's mind, and by having smartphones, everything is at their fingertips [4]. Indirectly, youngsters are learning the elements of English such as sentence structures and vocabulary through social media [5].

Years after the introduction of the internet, information and communication technologies (ICTs) were developed to aid language teaching [6]. However, due to the limited infrastructure and facilities in some developing countries, ICT has not been fully developed [6]. Recently, schools and higher institutions have begun focusing on and emphasizing teaching students 21st century skills [7]. It is essential to have the knowledge and be competent in technology to develop 21st century skills [8] as they consist of creativity, critical thinking, communication and collaboration [9]. Therefore, online learning has become a trend, and many software packages, online courses and mobile applications have been developed to, directly and indirectly, aid the teaching and learning process [10].

The effectiveness of the integration of education and ICT has been explored by several studies (e.g., [11]) as well as the efficiency of the technological learning environment (e.g., [12]). Since flipped learning is known for its numerous advantages, and the significant 
results from previous research cannot be argued with [13], it is best believed that integrating flipped learning into pedagogy is a great move. As there is little research on the integration of flipped learning and the unified theory of technology acceptance and use of technology (UTAUT), it is crucial to understand the acceptance of flipped learning to ensure the successfulness and effectiveness of integrating flipped learning with English language teaching. Hence, this study examined the unified theory of technology acceptance and use of technology (UTAUT) application in predicting English as a second language (ESL) lecturers' intention to use flipped learning.

Sustainable development is defined as development that satisfies current demands without jeopardizing future generations' ability to satisfy their own needs [14]. Economic, environmental and social elements are the three linked elements of a long-term, eternal sustainability process. Education for sustainability, which focuses on environmental sustainability through educational practices, and education of sustainability, which focuses on implementing sustainable forms of successful practice through educational development, leadership and innovation, have developed in two directions. Another way to look at sustainability is the e-learning practice that meets contemporary educational demands and allows for continual adaptation to change without exhausting its resource base or losing efficacy.

In supporting the sustainable and effective adaptation of the education and training system, the European Union (EU) has renewed the initiative policy The Digital Education Action Plan (2021-2027). The plan offers a long-term strategic vision for digital education. It addresses the hurdles and opportunities of the COVID-19 pandemic, promoting the importance of working together to bring education to the digital age. Lastly, it presents the quality of teaching through digital learning required for resilient remote learning [15]. It shows that there are still students who do not use technology and online learning tools.

In the recent literature, a wide range of pedagogies for education for sustainability in schools and higher institutions have been described. Participatory and inclusive education processes, transdisciplinary, cooperative and experiential learning and the use of the environment and community as learning resources are all general principles of sustainability pedagogies, all of which involve student-centered and interactive approaches to teaching and learning [16]. Integrating sustainability in higher education can be carried out by implementing various pedagogies with the integration of technology. According to recent studies by $[17,18]$, the COVID-19 pandemic led to rapid changes in shifting to remote teaching and learning. One of the possible pedagogies in visualizing remote teaching and learning is through flipped learning, and the adaptation of technology-enhanced learning. Hence, in understanding one's acceptance of flipped learning, the unified theory of technology acceptance and use of technology (UTAUT) must first be understood.

\subsection{Technological Pedagogical Content Knowledge}

Before technological pedagogical content knowledge (TPACK), pedagogical and content knowledge (PCK) was invented by [19], and it refers to knowledge that an educator possesses which can be delivered to learners through some pedagogical methods [20]. Decades later, and with the technological growth, Schulman's idea has been reviewed, revised and refined by adding the technological element. TPACK has gained popularity ever since it was introduced. Technological pedagogical content knowledge (TPACK) is a term for specific knowledge that integrates and optimizes technology to assist learners' learning [21]. The author of [22] stressed that technology can improve learners' learning, allow more opportunities for disadvantaged learners, make the school more favorable and engaging for learners and improve educators' professional development.

Figure 1 shows the main components of TPACK [20] which are content knowledge (CK), pedagogical knowledge (PK) and technological knowledge (TK). The three overlapped parts are technological pedagogical knowledge (TPK), technological content knowledge (TCK) and pedagogical content knowledge (PCK). The components and the overlapped components build up the main core area, technological pedagogical content knowl- 
edge (TPACK). The idea of this framework is not to place technology at the center of teaching and learning. Educators not only have to be technology-savvy but should also integrate all of the technology, content and pedagogy components into teaching and learning [23]. In other words, educators need to know when and how to integrate the appropriate technology into their content and instructions in the teaching and learning process of specific lessons.

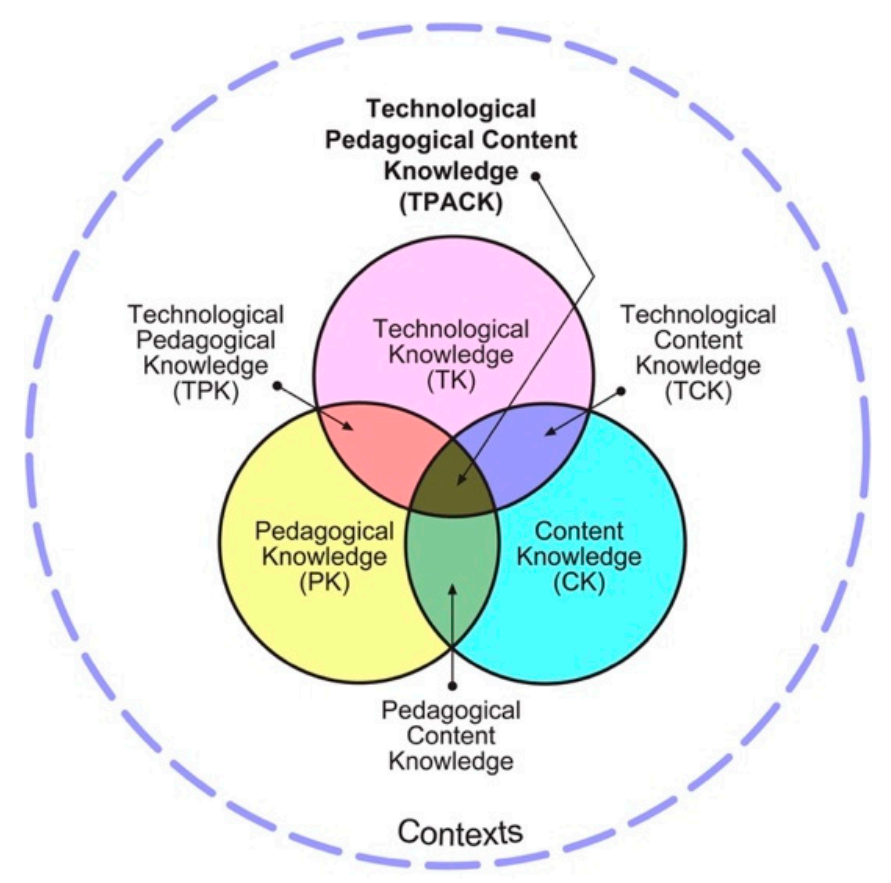

Figure 1. Technological pedagogical content knowledge (TPACK) model by Mishra and Koehler (2006).

Since teaching English as a foreign language has limited exposure to the target language, TPACK has been widely used for EFL when authentic sources can be achieved and used [24]. Moreover, TPACK can be regarded as a bridge between formal knowledge (delivered by educators) and practical knowledge (using technology). In applying TPACK for EFL, the author of [25] found that female teachers have higher TPACK development than male teachers. Nevertheless, there were no significant differences in academic achievement. The author of [26] also found that TPACK has a positive effect on primary English teachers in Taiwan.

\subsection{Flipped Learning and English as a Second Language}

Technology-based materials have been used in ESL/EFL education, such as the web and other communication tools, to make the ESL/EFL teaching and learning process more efficient. ESL education incorporates technology in order to improve English learning and teaching [27]. Technology has also been a significant factor in ESL/EFL education [28]. Furthermore, the expansion of online and technology-based ESL/EFL learning has created a new learning atmosphere for educators and learners alike [29]. It provides new learning styles and learning designs and also helps in improving accessibility to teaching and learning.

The rapid growth of globalization in education, business and commerce has boosted the necessity to learn the English language [30]. ESL and EFL education is becoming more reliant upon technology-based applications, especially in adult learning and higher education [31]. In non-English speaking countries, web-based applications and other similar technology-based devices can be integrated to develop a system of learning that overcomes the limitations of borders and distance that prevent people from learning English. Learning 
English has become more accessible among learners and educators [32,33]. Before incorporating flipped learning, students lack motivation and confidence, but soon after the implementation, they have a lot of hands-on, creative activities in class.

\subsection{Unified Theory of Technology Acceptance and Use of Technology}

The unified theory of technology acceptance and use of technology (UTAUT) model justifies technology acceptance. It has eight main components. The components comprise the theory of reasoned action (TRA), the technology acceptance model (TAM), the motivational model, the theory of planned behavior (TPB), the combined TAM and TPB, the model of personal computer utilization, innovation diffusion theory and social cognitive theory [34]. Behavioral intention is a predictor that is used in this model. This is the basic form of the unified theory of technology acceptance and use of technology (UTAUT) model:

Referring to Figure 2, the authors of [34] developed the unified theory of technology acceptance and use of technology (UTAUT) model that contains four constructs (performance expectancy, effort expectancy, social factors and facilitating conditions). Performance expectancy is defined as the degree to which the individual (in this research, a lecturer) believes that using technology will help them to achieve the numerous academic teaching goals at a typical university. The authors of [34] suggest that performance expectancy is the strongest of the four constructs in this model. Other researchers also supported this theory ([35-37] on acceptance models). Hence, adapting performance expectancy to the context of this study suggests that ESL lecturers will find flipped learning useful in teaching the English language. Effort expectancy is defined as the degree of ease associated with the use of a system. It is believed that an effort-oriented construct is expected to be more prominent in the early stages of a new behavior $[34,38,39]$. Hence, adapting effort expectancy to the context of this study suggests that ESL lecturers will find flipped learning easy to apply when teaching the English language. Social influence is defined as the degree to which an individual perceives important others to believe they should use the new system. This construct deals with the concept that someone's behavior is influenced by how they believe others will view them due to using technology. The importance of social factors becomes more significant in instructed environments, as hypothesized by [38]. Facilitating conditions refer to the degree to which an individual believes that an organizational and technical infrastructure exists to support the use of a system [40]. These four variables are essential in predicting ESL lecturers' intention to use flipped learning.

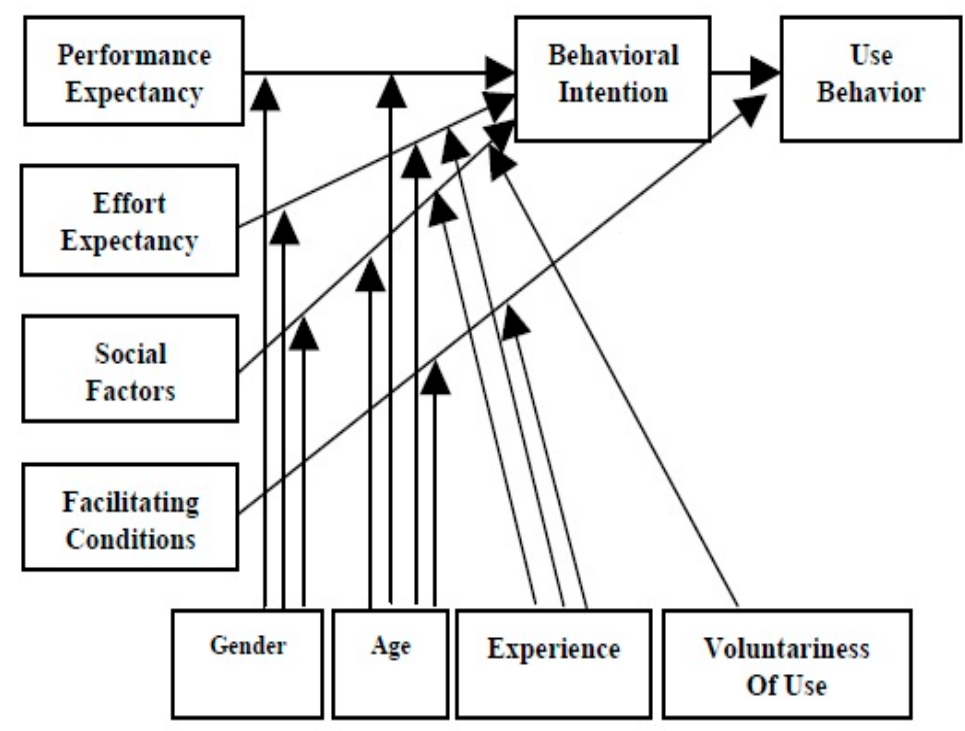

Figure 2. The unified theory of technology acceptance and use of technology (UTAUT) model by Venkatesh et al. (2003). 


\subsection{Constructivism}

Constructivism emerged in the United States and Europe in the 1970s during the educational reform period to recognize the role of the individual learner in making sense of the world. Humans have not programmed robots that can respond the same way to every stimulus given [41]. The constructivist learning theory encourages an active joint endeavor between teachers, students and their peers in fabricating meaning. The constructivist philosophical view of constructivism is knowledge created through communications with one another involving the society and setting. However, the outcome of the communication is not always complete [41]. Harasim also suggested that constructivist learning theory is an umbrella term for representing a range of perceptions on learning, and it is not one integrated entity.

The technology within constructivist learning is always compromised with learning environments (e.g., construction kits, microworlds, scaffolded intentional learning environments, learning networks or telecollaboration and learning management systems such as BlackBoard, WebCT or Moodle). The characteristics are as follows: avoiding oversimplification, preparing for the real world, stressing knowledge construction rather than reproduction, emphasizing meaningful contexts instead of abstraction of contexts, providing real-world environments, learning experiences being given further reflection, contexts and content depending on knowledge construction and collaborative construction held through social negotiation [41]. On the other hand, the constructivist approach in flipped learning should be an active practice, where learners must build their knowledge and make use of cooperative and collaborative learning, be given power in the learning procedure, be given chances to reflect and, lastly, gain meaningful learning experiences in order to enhance their learning based on this particular approach [42]. In this situation, educators play an important role in ensuring that these practices are incorporated in the flipped learning approach to achieve the mentioned objectives.

\section{Methodology}

This research used a quantitative approach. In this study, the researchers investigated whether the factors (performance expectancy, effort expectancy, social influence, facilitating conditions) have any significant relationships with ESL lecturers' intention to use flipped learning. In answering the research objective, four public universities were chosen in this study. Cluster sampling was used to select universities, as it is the most time- and cost-efficient probability design for large geographical areas. A larger sample size can be used to increase the accessibility of the sample group members [43]. In clustering the sample, the researchers categorized all universities under their region as a sampling frame. Additionally, each cluster was then numbered 1 up to 19. Lastly, a cluster sample was chosen using systematic random sampling, and each university represents the sample of this study. Since this study covers large and different geographical areas, only one university was selected from each region. The target populations of this study were ESL lecturers from selected universities: Universiti Utara Malaysia, Universiti Kebangsaan Malaysia, Universiti Teknikal Melaka and University Malaysia Pahang. In this study, only ESL lecturers were selected from each university. Lecturers were selected according to their faculty or department. After the universities had been decided, all ESL lecturers were involved in this survey. The research hypotheses of this study are as follows:

Hypothesis 1 (H1). Performance expectancy does not have any significant effect on Malaysian ESL lecturers' intention to use flipped learning.

Hypothesis 2 (H2). Effort expectancy does not have any significant effect on Malaysian ESL lecturers' intention to use flipped learning.

Hypothesis 3 (H3). Social influence does not have any significant effect on Malaysian ESL lecturers' intention to use flipped learning. 
Hypothesis 4 (H4). Facilitating conditions do not have any significant effect on Malaysian ESL lecturers' intention to use flipped learning.

Hence, the purpose of this study was to explore the application of the unified theory of technology acceptance and use of technology (UTAUT) in predicting ESL lecturers' intention to use the flipped learning approach. The research questions for this study are as follows:

- Does performance expectancy significantly affect Malaysian ESL lecturers' intention to use flipped learning?

- Does effort expectancy significantly affect Malaysian ESL lecturers' intention to use flipped learning?

- Does social influence significantly affect Malaysian ESL lecturers' intention to use flipped learning?

- Do facilitating conditions significantly affect Malaysian ESL lecturers' intention to use flipped learning?

In this study, the total population of ESL lecturers within the four chosen universities was unknown. In estimating the sample size, Cochran's formula was used. Cochran's formula was used because it allows researchers to estimate a sample size according to the researchers' preferred level of precision, preferred confidence level and proportion of the traits in a population [44]. Cochran's formula is extensively used in estimating unknown sample sizes compared to other formulas [45]. Therefore, based on the formula, the calculated sample size was 166 . However, 206 ESL lecturers responded to the questionnaire.

As for the data collection, the researchers first asked for supervisors to provide them with a formal consent letter to be attached to the online survey. Then, the researchers approached one representative (English lecturer) from each faculty /department to share the questionnaire link with all of the other English lecturers within the faculty/department. Later on, the representatives forwarded the link to their ESL colleagues using their official university emails and the Whatsapp application. The researchers used the Bitlinks website to generate a unique link for the online questionnaire. Meanwhile, the questionnaire was developed using Google Forms.

A brief introduction of the purpose of having the questionnaire and the researchers' details were included in the questionnaire if respondents wanted to provide any personal feedback or comments to the researchers. The researchers did not state any specific time for respondents to complete their questionnaire. However, the researchers had to wait for a month for respondents to complete the questionnaire. A week after that, the researchers did not receive any other responses. Hence, we decided to start analyzing the data. In this study, the survey instrument was adapted from instruments developed by [46], and some modifications were made to meet the purpose of the study. Table 1 shows the items in the questionnaire adapted from [46] and the scale reliability of Cronbach's alpha value for each item and each construct.

Table 1. The scale reliability of Cronbach's alpha value for each item.

\begin{tabular}{|c|c|c|c|c|}
\hline Constructs & Item & Corrected Item-Total Correlation & Decision & Cronbach's $\alpha$ \\
\hline \multirow{3}{*}{$\begin{array}{l}\text { Performance } \\
\text { Expectancy (PE) }\end{array}$} & I find Flipped Learning useful for teaching ESL. & 0.695 & Accept & \multirow{3}{*}{0.895} \\
\hline & I find using Flipped Learning for teaching ESL will ease interaction. & 0.858 & Accept & \\
\hline & I find it easy to become skillful at using Flipped Learning for teaching & 0.827 & Accept & \\
\hline \multirow{3}{*}{$\begin{array}{c}\text { Effort } \\
\text { Expectancy (EE) }\end{array}$} & $\begin{array}{l}\text { I find Flipped Learning easy to use for teaching ESL. } \\
\text { Using Flipped Learning for teaching ESL is easy for me. }\end{array}$ & $\begin{array}{l}0.720 \\
0.754\end{array}$ & $\begin{array}{l}\text { Accept } \\
\text { Accept }\end{array}$ & \multirow{3}{*}{0.883} \\
\hline & $\begin{array}{l}\text { I find Flipped Learning appealing to me if majority of my colleague } \\
\text { used it. }\end{array}$ & 0.843 & Accept & \\
\hline & $\begin{array}{c}\text { I would use Flipped Learning in teaching ESL if my boss has } \\
\text { encouraged using it. }\end{array}$ & 0.794 & Accept & \\
\hline \multirow{2}{*}{$\underset{(\mathrm{SI})}{\text { Social Influence }}$} & $\begin{array}{l}\text { I would use Flipped Learning in teaching if my boss has been helpful in } \\
\text { the use of Flipped Learning in teaching. }\end{array}$ & 0.769 & Accept & \multirow[t]{2}{*}{0.870} \\
\hline & $\begin{array}{c}\text { I would likely get enough practice for teaching if I use Flipped Learning } \\
\text { for teaching ESL. }\end{array}$ & 0.769 & Accept & \\
\hline \multirow{3}{*}{$\begin{array}{l}\text { Facilitating } \\
\text { Conditions (FC) }\end{array}$} & I have the resources necessary to use Flipped Learning in teaching ESL. & 0.619 & Accept & \multirow{3}{*}{0.787} \\
\hline & I have the knowledge necessary to use Flipped Learning in teaching & 0.690 & Accept & \\
\hline & $\begin{array}{l}\text { There is a specific person available for assistance with any technical } \\
\text { problem I may encounter regarding Flipped Learning. }\end{array}$ & 0.602 & Accept & \\
\hline
\end{tabular}


In assessing the normality and outliers, the $\mathrm{Z}$ scores were found to be below 3.00, and all of the Mahalanobis values were greater than 40.998 . Therefore, it could be concluded that there were no outliers in the data, and the data were considered normal. This sample also followed the prerequisite minimum sample size of 200 samples to ensure stable structural equation modeling (SEM) results [47].

All items in performance expectancy, effort expectancy, social influence and facilitating conditions returned reliable values.

\section{Results and Discussion}

This section discusses the results of this study that comprise the average variance extracted, the factor loadings and composite reliabilities of each item, the fit indices of the whole model and, lastly, the regression path coefficient and its significance. Table 2 presents the average variance extracted (AVE), factor loadings and composite reliability (CR).

Table 2. CFA results for performance expectancy.

\begin{tabular}{|c|c|c|c|c|}
\hline Construct & Item & Factor Loading & AVE (Above 0.5) & CR (Above 0.6) \\
\hline \multirow{4}{*}{$\begin{array}{c}\text { Performance } \\
\text { Expectancy }(\mathrm{PE})\end{array}$} & $\begin{array}{l}\text { I find Flipped Learning useful for } \\
\text { teaching ESL }\end{array}$ & 0.980 & \multirow{4}{*}{0.881} & \multirow{4}{*}{0.967} \\
\hline & $\begin{array}{l}\text { I find using Flipped Learning for } \\
\text { teaching ESL will ease interaction }\end{array}$ & 0.975 & & \\
\hline & $\begin{array}{c}\text { I find it easy to become skillful at } \\
\text { using Flipped Learning for } \\
\text { teaching ESL }\end{array}$ & 0.904 & & \\
\hline & $\begin{array}{l}\text { I find Flipped Learning easy to use } \\
\text { for teaching ESL }\end{array}$ & 0.891 & & \\
\hline
\end{tabular}

The table above shows that all factor loadings are greater than 0.6 , ranging from 0.891 to 0.980 . The average variance extracted also displays a value of more than 0.5 $(\mathrm{AVE}=0.881)$. This demonstrates that convergent validity was established. On the other hand, the composite reliability of the performance expectancy (PE) construct has a value higher than $0.60(C R=0.967)$, indicating good internal consistency. Meanwhile, the average variance extracted (AVE), factor loadings and composite reliability (CR) for effort expectancy are presented in Table 3.

Table 3. CFA results for effort expectancy.

\begin{tabular}{ccccc}
\hline Construct & Item & Factor Loading & AVE (Above 0.5) & CR (Above 0.6) \\
\hline Effort Expectancy (EE) & $\begin{array}{c}\text { Using Flipped Learning for } \\
\text { teaching ESL is easy for me. } \\
\text { I find Flipped Learning appealing } \\
\text { to me if majority of my colleague } \\
\text { used it. }\end{array}$ & 0.980 & 0.760 & 0.861 \\
\hline
\end{tabular}

The table above shows that both factor loadings are greater than 0.6 , ranging from 0.748 to 0.980 . The average variance extracted also displays a value of more than 0.5 $(\mathrm{AVE}=0.760)$. This shows that convergent validity was established. On the other hand, the composite reliability of the effort expectancy (EE) construct has a value higher than 0.60 $(C R=0.861)$, specifying adequate internal consistency. For social influence, the average variance extracted (AVE), factor loadings and composite reliability (CR) are presented in Table 4. 
Table 4. CFA results for social influence.

\begin{tabular}{ccccc}
\hline Construct & Item & Factor Loading & AVE (Above 0.5) & CR (Above 0.6) \\
\hline & $\begin{array}{c}\text { I would use Flipped Learning in } \\
\text { teaching if my boss has been } \\
\text { helpful in the use of Flipped } \\
\text { Learning in teaching. }\end{array}$ & 0.922 & 0.821 & 0.902 \\
& $\begin{array}{c}\text { I would likely get enough practice } \\
\text { for teaching if I use Flipped } \\
\text { Learning for teaching ESL. }\end{array}$ & 0.890 & \\
\hline
\end{tabular}

The table above shows that both factor loadings are greater than 0.6 , ranging from 0.890 to 0.922 . The average variance extracted also shows a value of more than 0.5 (AVE $=0.821$ ). This shows that convergent validity was established. Meanwhile, the composite reliability of the social influence (SI) construct has a value higher than $0.60(C R=0.902)$, indicating adequate internal consistency. Finally, the average variance extracted (AVE), factor loadings and composite reliability (CR) for facilitating conditions are presented in Table 5.

Table 5. CFA results for facilitating conditions.

\begin{tabular}{ccccc}
\hline Construct & Item & Factor Loading & AVE (Above 0.5) & CR (Above 0.6) \\
\hline $\begin{array}{c}\text { Facilitating Conditions } \\
\text { (FC) }\end{array}$ & $\begin{array}{c}\text { I have the resources necessary to use } \\
\text { Flipped Learning in teaching ESL. } \\
\text { I have the knowledge necessary to use } \\
\text { Flipped Learning in teaching ESL. } \\
\text { There is a specific person available for } \\
\text { assistance with any technical problem } \\
\text { I may encounter regarding Flipped } \\
\text { Learning. }\end{array}$ & 0.901 & 0.8891 & 0.941 \\
\hline
\end{tabular}

The table above shows that all factor loadings are greater than 0.6 , ranging from 0.889 to 0.960 . The average variance extracted also shows a value of more than 0.5 (AVE $=0.841$ ). This shows that convergent validity was established. Meanwhile, the composite reliability of the facilitating conditions (FC) construct has a value higher than $0.60(\mathrm{CR}=0.941)$, indicating adequate internal consistency. Table 5 shows that the fit indices indicate a good model fit after many items have been discarded.

The chi-square/df ratio is 2.791 (recommended <3.0), and the comparative fit index (CFI) is 0.907 , which is more than 0.90 . A value of 0.90 is needed in order to support that misspecified models are not accepted [48]. The root mean square error of approximation (RMSEA) is 0.093 (recommended $<0.10$ ), which is measured as an indication of a good fit [49]. Table 6 shows the regression path coefficient and its significance.

Table 6. The fit indices demonstrating a good model fit.

\begin{tabular}{|c|c|c|c|c|}
\hline Name of Index Category & Name of Index & Index Value & Level of Acceptance & Comments \\
\hline Absolute Fit & RMSEA & 0.093 & RMSEA 0.05 to 0.10 acceptable & The required level is achieved \\
\hline Incremental Fit & CFI & 0.907 & CFI $>0.90$ & The required level is achieved \\
\hline Parsimonious Fit & ChiSq/df & 2.791 & Chisq/df $<3.0$ & The required level is achieved \\
\hline
\end{tabular}

Table 7 shows that performance expectancy does not significantly affect the ESL lecturers' intention to use flipped learning $(\beta=-0.273, p$-value $>0.05)$. This finding is inconsistent with previous studies that claimed flipped learning provides better engagement than traditional classes, and that educators' presence is not strictly necessary. Using flipped learning also makes the teaching and learning process more efficient, especially in ESL/EFL classes. By having flipped learning as a teaching medium, teachers can overcome the limitation of distance too $[13,28,32]$. Performance expectancy is not only important for 
educators. When issues of educators' performance are being discussed, students do not represent an exception in being included in the topic because educators' performance is usually measured by students' achievement [50].

Table 7. The regression path coefficient and its significance.

\begin{tabular}{|c|c|c|c|c|c|c|c|}
\hline & & & Estimate & S.E. & C.R. & $\mathbf{P}$ & Result \\
\hline INT & $\leftarrow$ & PE & -0.189 & 0.116 & -1.630 & 0.103 & Not Significant \\
\hline INT & $\leftarrow$ & $\mathrm{EE}$ & 0.025 & 0.113 & 0.225 & 0.822 & Not Significant \\
\hline INT & $\leftarrow$ & SI & 0.496 & 0.080 & 6.231 & 0.000 & Significant at 0.001 \\
\hline INT & $\leftarrow$ & $\mathrm{FC}$ & 0.076 & 0.051 & 1.489 & 0.137 & Not Significant \\
\hline
\end{tabular}

As for effort expectancy, the results show that effort expectancy does not significantly affect ESL lecturers' intention to use flipped learning $(\beta=-0.042, p$-value $>0.05)$. This result is consistent with a few studies where effort expectancy was found to be non-significant in predicting behavioral intentions [51,52]. This contradicts a study conducted by [53] which stated that, by using flipped learning, teachers might have to invest more time initially, but it pays off as they have an easier workload in the future and students can enjoy deeper learning. A few other studies also found that effort expectancy is a strong predictor in predicting behavioral intentions [54-60]. However, this result shares the same finding with a few studies where effort expectancy was found to be non-significant in predicting behavioral intentions [51,52]. As suggested by [23], educators are expected to be technology-savvy, but they must also know how to integrate the technology into the content and instructions. This shows that powerful technological pedagogical content knowledge (TPACK) could enhance ESL teaching and learning.

Social influence does have a significant effect on ESL lecturers' intention to use flipped learning $(\beta=0.457, p$-value $<0.05)$. This result is congruent with previous research by [61] showing that persuasion by colleagues and administrators is better than preaching. Faculties can work together in assigning the flipped learning course and sharing the resources [53]. A survey by [62] found that behavioral intention is significantly predicted by social influence. The authors of $[57,59,60,63]$ also found that social influence is a strong predictor in predicting behavioral intention. This implies that colleagues and administrators play an important role in influencing ESL lecturers in adopting flipped learning. Nonetheless, the authors of [51,52] found that social influence is not a significant factor in predicting behavioral intention.

In a study conducted by [64] on the factors impacting ESL learners in technology acceptance, the zone of proximal development (ZPD) was applied, and the author found that one of the important factors that affect students in accepting and using a technology is the ESL instructor themself. The ESL instructor guides the students to use the technology, asks them to complete the task and provides a community to learn ESL and the targeted technology together with their friends. Some of the students claim that they are more affected by their friends than an instructor. This highlights that both guidance (ZPD) from educators and social influence (in this case, classmates) go hand in hand in applying technology in the ESL classroom.

Finally, facilitating conditions do not significantly affect ESL lecturers' intention to use flipped learning $(\beta=0.128, p$-value $>0.05)$. A support system that offers encouraging feedback will create well-integrated, effective educators by helping them feel good about themselves to dedicate their time and energy to satisfy others [65]. As a strong predictor, facilitating conditions are believed to be an important factor in adopting a new system, in this case, flipped learning. The University of Washington and Vanderbilt University provide an instructional design resource center for lecturers to help them in teaching and learning [66]. The authors of [63] also agreed that behavioral intention can be predicted through facilitating conditions. Nevertheless, [62] found facilitating conditions to be a non-significant predictor in predicting behavioral intention. 
In integrating technology in the classroom, especially in ESL teaching and learning, facilitating conditions are important to educators. The author of [64] proved that students need to be facilitated with supporting staff and external helpers. As constructivism proponents suggest, collaborating with teachers, students and peers is also important to have a positive society and setting. While integrating technology in ESL, having a support team could benefit both lecturers and students in making ESL teaching and learning easier.

From a different perspective, it can be said that TPACK could help students and educators. However, the technology part, together with the pedagogy and content knowledge, must be balanced. Hence, the utmost learning outcomes could be achieved. Somehow, there are arguments on the effectiveness of TPACK. In contrast, a study conducted by [67] showed different results, where TPACK was found insignificant in teaching literature in Ethiopia, and educators' TPACK was also found to be less applied in the classroom. In addition, there are several studies that found a number of teachers who refused to integrate technology to assist their teaching and learning [68-71]. They are probably not technologyliterate, or applying technology might be time-consuming for them. With the integration of TPACK, constructivism, ZPD and experiential learning theory, flipped learning is hoped to be an effective way for lecturers to teach and improve students' ESL knowledge and performance.

\section{Conclusions}

In conclusion, performance expectancy, effort expectancy and facilitating conditions do not significantly correlate with ESL lecturers' intention to use the flipped learning approach in the classroom. However, only social influence was found to be significant. This shows that influence by a colleague is the most important predictor for ESL lecturers in deciding whether to use flipped learning or not in their teaching and learning process. This study is expected to provide insight to educators and stakeholders and benefits to students, especially in boosting students' critical thinking skills by employing technology in teaching and learning. Based on the results, a few implications were drawn. As for the theoretical implication, it can be seen that social influence is a strong predictor in determining ESL lecturers' intention to use flipped learning. This study utilized the unified theory of technology acceptance and use of technology (UTAUT), and empirical data were established in the methodological implication. Similar findings to past studies were gained; however, replication of this study can still be conducted with some modifications of the samples or settings to obtain different results. The pedagogical implication from this study is certainly an important aspect to be emphasized to help educators determine the strong predictors. By distinguishing the strong predictors, this could help educators to incorporate or enhance certain aspects in applying flipped learning, especially in managing computer-related tasks, software or any internet-based applications to be applied in the classroom.

Last but not least, from the policy perspective, flipped learning should be employed in all universities: public and private ones, colleges, college universities and schools. Policymakers could consider coaching educators in using flipped learning, especially in managing technology to enhance ESL teaching and learning. They can also consider affording a better environment in integrating technology into education, especially in second language learning. In addition, it is proposed to have further studies conducted on the following four predictors: performance expectancy, effort expectancy, social influence and facilitating conditions, as the researchers had an inadequate number of respondents. Larger sampling could perhaps develop a different result. Since this study was steered towards public universities, more studies could be conducted on private universities, polytechnics, college universities and community colleges.

Author Contributions: All authors contributed to several aspects of the study, specifically, conceptualization, S.F.A.R., M.M.Y. and H.H.; methodology, S.F.A.R., M.M.Y., and H.H.; formal analysis, investigation, resources and data curation, S.F.A.R., M.M.Y. and H.H.; writing-original draft prepa- 
ration, S.F.A.R.; writing, review and editing, S.F.A.R. and H.H.; supervision, M.M.Y. and H.H. All authors have read and agreed to the published version of the manuscript.

Funding: This research was funded by FPEND Research Grants, grant number GG-2020-027 and GG-2019-077.

Institutional Review Board Statement: Not applicable.

Informed Consent Statement: Informed consent was obtained from all subjects involved in this study.

Data Availability Statement: Data sharing not applicable.

Conflicts of Interest: The authors declare no conflict of interest.

\section{References}

1. Yemma, D.M. Impacting Learning for 21st Century Students: A Phenomenological Study of Higher Education Faculty Utilizing A Flipped Learning Approach. Ph.D. Thesis, Robert Morris University, Moon Twp, PA, USA, 2015.

2. Yeop, M.A. Implementation of ICT Policy (Blended Learning Approach): Investigating factors of Behavioural Intention and Use Behaviour. Int. J. Instr. 2019, 12, 767-782. [CrossRef]

3. Sun, Y.; Gao, F. Exploring the roles of school leaders and teachers in a school-wide adoption of flipped classroom: School dynamics and institutional cultures. Br. J. Educ. Technol. 2019, 50, 1241-1259. [CrossRef]

4. $\quad$ Overmyer, J. Flipped Classrooms 101. Principal, No. September/October, 2012; 46-47.

5. Shazali, S.S.; Shamsudin, Z.H.; Yunus, M.M. Instagram: A Platform to Develop Student's Writing Ability. Int. J. Acad. Res. Bus. Soc. Sci. 2019, 9, 88-98. [CrossRef]

6. Saad, N.S.M.; Yunus, M.M.; Embi, M.A. The Intersection between Out-of-class Language Learning Strategies and In-class Activities. Adv. Lang. Lit. Stud. 2013, 4, 132-140. [CrossRef]

7. Opfer, A.R.S.V.D. Learning 21st Century Skills Requires 21st Century Teaching. Kappan 2012, 94, 8-13.

8. Zainuddin, Z.; Perera, C.J. Exploring students' competence, autonomy and relatedness in the flipped classroom pedagogical model. J. Furth. High. Educ. 2019, 43, 115-126. [CrossRef]

9. Byer, D.; Fadel, C.; Fox, C.; Givens, A.; Kellogg, L. Maximizing the Impact: The Pivotal Role of Technology in A 21st Century Education System; Pearson: London, UK, 2007.

10. Alebrahim, F.H. Implementation Evaluation Study: Flipped Classroom Professional Development with Faculty Members to Enhance Students' Engagement in Higher Education; University of Northern Colorado: Greeley, CO, USA, 2016.

11. Blanc, V. The experience of embodied presence for the hybrid dance/movement therapy student: A qualitative pilot study. Internet High. Educ. 2018, 38, 47-54. [CrossRef]

12. Sun, Z.; Lin, C.H.; Wu, M.; Zhou, J.; Luo, L. A tale of two communication tools: Discussion-forum and mobile instant-messaging apps in collaborative learning. Br. J. Educ. Technol. 2018, 49, 248-261. [CrossRef]

13. Bergmann, J.; Sams, A. Flip Your Classroom: Reach Every Student in Every Class Every Day; International Society for Technology in Education: Washington, DC, USA, 2012.

14. Brundtland, G.H. World Commission on Environment and Development. In Our Common Future; Oxford University Press: Oxford, UK, 1987.

15. European Commission. Digital Education Action Plan (2021-2027). 2021. Available online: https:/ / ec.europaeu/education/ education-in-the-eu/digital-education-action-plan_en (accessed on 8 July 2021).

16. Albareda-Tiana, S.; García-González, E.; Jiménez-Fontana, R.; Solís-Espallargas, C. Implementing pedagogical approaches for ESD in initial teacher training at Spanish Universities. Sustainability 2019, 11, 4927. [CrossRef]

17. Bojović, Ž.; Bojović, P.D.; Vujošević, D.; Šuh, J. Education in times of crisis: Rapid transition to distance learning. Comput. Appl. Eng. Educ. 2020, 28, 1467-1489. [CrossRef]

18. Mishra, L.; Gupta, T.; Shree, A. Online teaching-learning in higher education during lockdown period of Covid-19 pandemic. Int. J. Educ. Res. Open 2020, 1, 100012. [CrossRef]

19. Shulman, L.S. Those who understand: Knowledge growth in teaching. Educ. Res. 1986, 15, 4-14. [CrossRef]

20. Chai, C.S.; Koh, J.H.L.; Tsai, C.C. A Review of Technological Pedagogical Content Knowledge. Educ. Technol. Soc. 2013, 16, 31-51.

21. Mishra, P.; Koehler, M.J. Technological Pedagogical Content Knowledge: A framework for teacher knowledge. Teach. Coll. Rec. 2006, 108, 1017-1054. [CrossRef]

22. Zucker, A.A. Transforming Schools with Technology: How Smart Use of Digital Tools Helps Achieve Six Key Education Goals; Harvard Education Press: Cambridge, MA, USA, 2008.

23. Koehler, M.; Mishra, P.; Yahya, K. Tracing the development of teacher knowledge in a design seminar: Integrating content, pedagogy, and technology. Comput. Educ. 2007, 49, 740-762. [CrossRef]

24. Liu, S.; Liu, H.; Yu, Y.; Li, Y.; Wen, T. TPACK: A New Dimension to EFL Teachers' PCK. J. Educ. Hum. Dev. 2014, 3, 681-693.

25. Oz, H. Assessing Pre-service English as a Foreign Language Teachers' Technological Pedagogical Content Knowledge. Int. Educ. Stud. 2015, 8, 119-130. [CrossRef] 
26. Tai, S.D. From TPACK-in-Action Workshops to English Classrooms: CALL Competencies Developed and Adopted into Classroom Teaching. Graduate Theses and Dissertations, Iowa State University, Ames, IA, USA, 2013.

27. Lee, G.; Wallace, A. Flipped Learning in the English as a Foreign Language Classroom: Outcomes and Perceptions. TESOL Q. 2018, 52, 62-84. [CrossRef]

28. Foulger, T.; Jimenez-Silva, T. Enhancing the writing development of English language learners: Educators' perceptions of common technology in project-based learning. J. Res. Child. Educ. 2007, 22, 109-124. [CrossRef]

29. Rubí, J.V. Learning How To Learn: Students' Interactions With The Online Components Of A Flipped Spanish Language Program. Ph.D. Thesis, University of Iowa, Iowa City, IA, USA, 2017.

30. Largo, K.J. The Flipped Learning Model: Teachers' Perceptions and Usage in Secondary Education; Illinois State University: Normal, IL USA, 2017.

31. Santikarn, B.; Wichadee, S. Flipping the classroom for English language learners: A study of learning performance and perceptions. Int. J. Emerg. Technol. Learn. 2018, 13, 123-135. [CrossRef]

32. Wang, R.; Sutton, L.C. Effects of Learner Control with Advisement on English-As-A-Second—Language Student in A Web-Based Learning Environment. Int. J. Instr. Media 2002, 29, 317-324.

33. Rajesh, M. Revolution in Communication Technologies: Impact on Distance Education. Turk. Online J. Distance Educ. 2015, 1, 62-88. [CrossRef]

34. Venkatesh, V.; Morris, M.G.; Davis, F.D.; Davis, G.B. User Acceptance of Information Technology: Toward A Unified View. MIS Q. 2003, 27, 425-478. [CrossRef]

35. Agarwal, R.; Prasad, J. The Role of Innovation Characteristics and Perceived Voluntariness in the Acceptance of Information Technology. Decision Support Systems. Decis. Sci. 1997, 28, 557-582. [CrossRef]

36. Compeau, D.R.; Higgins, C.A. Computer Self-Efficacy: Development of a Measure and Initial Test. MIS Q. 1995, 19, $189-211$. [CrossRef]

37. Taylor, S.; Todd, P.A. Understanding Information Technology Usage: A Test of Competing Models. Inf. Syst. Res. 1995, 6, 144-176. [CrossRef]

38. Venkatesh, V.; Davis, F.D. A Theoretical Extension of the Technology Acceptance Model: Four Longitudinal Field Studies. Manage. Sci. 2000, 46, 186-204. [CrossRef]

39. Venkatesh, V.; Brown, S.; Hoehle, H. Understanding Technology Adoption in the Household Context: A Comparison of Seven. Eur. Conf. Inf. Syst. 2012, 35, 1-13.

40. Akbar, F. What Affects Students' Acceptance and Use of Technology? Senior Honors Thesis, Dietrich College of Humanities and Social Sciences, Pittsburgh, PA, USA, 2013.

41. Harasim, L. Learning Theory and Online Technologies; Taylor \& Francis Group: New York, NY, USA, 2012.

42. Ally, M. Foundations of educational theory for online learning. In The Theory and Practice of Online Learning; Anderson, T., Ed.; Athabasca University Press: Edmonton, AB, Canada, 2008.

43. Sekaran, U.; Bougie, R. Research Methods for Business: A Skill-Building Approach, 6th ed.; Wiley: New York, NY, USA, 2013.

44. Cochran, W.G. Sampling Techniques, 3rd ed.; Wiley: New York, NY, USA, 1977.

45. Choudhury, G. An Investigation on the Reliability of a Questionnaire used to analyze the socio-economic background of the students of class VIII of some schools of Guwahati. Int. J. Stat. Anal. 2013, 3, 185-200.

46. Hashim, H.; Yunus, M.M.; Embi, M.A. Factors Influencing Polytechnic English as Second Language (ESL) Learners' Attitude and Intention for Using Mobile Learning. Asian ESP J. 2018, 14, 195-208.

47. Hair, J.F.; Black, W.C.; Babin, B.J.; Anderson, R.E.; Tatham, R.L. Multivariate Data Analysis; Prentice Hall: New Jersey, NJ, USA, 2006.

48. Newsom, J.T. Some Clarifications and Recommendations on Fit Indices. Struct. Equ. Model. 2017, $201,1-4$.

49. MacCallum, R.C.; Browne, M.W.; Sugawara, M.H. Power Analysis and Determination of Sample Size for Covariance Structure Modelling. Psychol. Methods 1996, 1, 130-149. [CrossRef]

50. Steinmayr, R.; Weidinger, A.F.; Schwinger, M.; Spinath, B. The importance of students' motivation for their academic achievementreplicating and extending previous findings. Front. Psychol. 2019, 10, 1730. [CrossRef]

51. Heerink, M.; Kröse, B.J.; Wielinga, B.; Evers, V. Measuring the influence of social abilities on acceptance of an interface robot and a screen agent by elderly users. In Proceedings of the People and Computers XXIII Celebrating People and Technology (HCI), Cambridge, UK, 1-5 September 2009; BCS Learning and Development Limited; pp. 430-439.

52. Schaupp, L.; Carter, L.; Hobbs, J. E-File Adoption: A Study of U.S. Taxpayers Intentions. In Proceedings of the 42nd Hawaii International Conference on System Sciences, Washington, DC, USA, 5-8 January 2009.

53. Seaboyer, J. The Role of Technology-Assisted Assessment in Fostering Critical Reading in Undergraduate Literary Studies. In Proceedings of the International Computer Assisted Assessment Conference, Southampton, UK, 28-30 October 2013.

54. Biemans, M.; Swaak, J.; Hettinga, M.; Schuurman, J. Involvement Matters: The Proper Involvement of Users and Behavioural Theories in the Design of a Medical Teleconferencing Application. In Proceedings of the 2005 international ACM SIGGROUP conference on Supporting group work, New York, NY, USA, 6-9 November 2005.

55. Oshlyansky, H.; Cairns, L.; Thimbleby, P. Validating the Unified Theory of Acceptance and Use of Technology (UTAUT) Tool Cross-Culturally. In Proceedings of the 21st BCS HCI Group Conference, Swindon, UK, 3-7 September 2007. 
56. Šumak, M.; Polančič, B.; Heričko, G. An Empirical Study of Virtual Learning Environment Adoption Using UTAUT. In Proceedings of the 2010 Second International Conference on Mobile, Hybrid, and On-Line Learning, Washington, DC, USA, 10-16 February 2010.

57. Cheng, D.; Liu, G.; Song, Y.F.; Qian, C. Adoption of Internet Banking: An Integrated Model. In Proceedings of the 4th International Conference on Wireless Communications, Networking and Mobile Computing, Dalian, China, 12-14 October 2008.

58. Fang, W.C.; Li, M.W.; Liu, C.W. Measurement of the Knowledge-Sharing Efficacy of web2.0 Site Constructed On the Basis of Knowledge-Based Systems by Applying the Model of UTAUT: Evidence of the Early Adopters. In Proceedings of the 3rd International Conference on Innovative Computing Information and Control, ICICIC'08, Washington, DC, USA, 18-20 June 2008.

59. Carlsson, C.; Carlsson, J.; Hyvonen, K.; Puhakainen, J.; Walden, P. Adoption of Mobile Devices/Services-Searching for Answers with the UTAUT. In Proceedings of the 39th Hawaii International Conference on System Science, Washington, DC, USA, 4 January 2006.

60. Wu, P.; Tao, Y.; Yang, Y. Using UTAUT to Explore the Behaviour of 3G Mobile Communication Users. In Proceedings of the The International Conference on Industrial Engineering and Engineering Management (IEEM), Singapore, 2-5 December 2007.

61. Weimer, M. Learner-Centered Teaching: Five Key Changes to Practice; Jossey-Bass: San Francisco, CA, USA, 2013.

62. Maldonado, U.P.; Khan, G.F.; Moon, J.; Rho, J.J. E-learning motivation, Students' Acceptance/Use of Educational Portal in Developing Countries. In Proceedings of the 4th International Conference on Computer Sciences and Convergence Information Technology, Seoul, Korea, 24-26 November 2009; pp. 1431-1441. [CrossRef]

63. He, D.; Lu, Y. Consumers Perceptions and Acceptances towards Mobile Advertising: An Empirical Study in China. In Proceedings of the International Conference Wireless Communications, Networking and Mobile Computing, New York, NY, USA, 12-16 August 2007.

64. Liu, M. The application of a flipped classroom model in modern educational technology. J. Contin. Eng. Educ. Life Long Learn. 2017, 27, 57.

65. Aaronsohn, E. Going Against the Grain: Supporting the Student-Centered Teacher; Corwin Press: Thousand Oaks, CA, USA, 1996.

66. Aronson, N.; Arfstrom, K.M.; Tam, K. Flipped Learning in Higher Education; Pearson: London, UK, 2013.

67. Plasencia, A.; Navas, N. MOOCs, the Flipped Classroom, and Khan Academy Practices: The Implications of Augmented Learning; Springer: Cham, Switzerland, 2014; pp. 11-21.

68. Abera, B. Applying a Technological Pedagogical Content Knowledge Framework in Ethiopian English Language Teacher Education; IGI Global: Lisbon, Portugal, 2014.

69. Conlon, M.; Simpson, T. Silicon Valley versus Silicon Glen: The impact of computers upon teaching and learning: A. comparative study. Br. J. Educ. Technol. 2003, 34, 137-150. [CrossRef]

70. Cuban, L. Oversold and Underused-Computers in the Classroom; Harvard University Press: Cambridge, UK, 2001.

71. Watson, D. Pedagogy before Technology: Re-thinking the relationship between ICT and teaching. Educ. Inf. Technol. 2001, 6, 251-266. [CrossRef] 